\title{
OOFRESPONDFINOE.
}

\section{RECENT PAPERS ON THE DURHAM COALFIELD.}

Sir,-In the Geological Magazine of July there is a letter from Mr. J. T. Stobbs criticizing two papers which appeared in the April and May numbers. I desire to give a short reply to this letter. The chief reason for publishing the paper dealing with the borings at Cotefield Close and Sheraton was that the cores gave information regarding an almost totally unknown facies of the Middle Magnesian Limestone, and therefore more stress was laid on the description of the Permian rocks than on those of the Coal-measures, which were only dealt with in a general manner. It may, however, be possible to deal with these and other sections in the latter strata on a subsequent occasion. I came to the conclusion after consultation with the mining engineer that the boring at Cotefield Close had entered the Coal-measures beneath the Brockwell Seam from comparison with other sections, from the character of the strata and from the structure of the country. It is true that the coals in the Ganister Series have been worked in the western part of the coalfield, but over a large portion of it the exact nature of the strata occurring beneath the Brockwell Seam are not well known. The coal-seams in these beds are not constant, are thin, and seldom worked. There are a few borings in the Ganister Series, but the strata have never been properly correlated or described. The late Professor Lebour wrote some vears ago, "As a consequence of the small importance of the coal-seams known to exist in the Ganister Beds not many detailed sections of sinkings and borings can be referred to for details in the strata." These words are still true and especially true for the deeper parts of the coalfield beneath the Magnesian Limestone of Durham. Further, from a palæontological standpoint, not only the Ganister Series but the whole of the Coal-measures of Northumberland and Durham may be said to be little known. No exact knowledge of the zones in this coalfield has yet been obtained. Aviculopecten (Pterinopecten) papyraceus, Carbonicola robusta, and Anthracomya Phillipsi appear to be confined to definite horizons, but there still remains much work to be done on the palæontology of these rocks. I think that when the Coal-measures of the Northern Coalfeld are zoned it will be found that Aviculopecten papyraceus is confined to the Ganister Series in this area. My note regarding it may not be found to be so quaint as Mr. Stobbs supposes. I used the generic name Aviculopecten because I was referring to Professor Lebour's discovery of this fossil. If $\mathrm{Mr}$. Stobbs knows anyone who is thoroughly acquainted with the Ganister Series of Northumberland and Durham and could prevail upon him to write an account of these beds I am sure geologists would feel indebted to him.

In the paper "The highest Coal-measures in the Durbam Coalfield" an attempt was made to give an exact description (which had never been done) of the section in which Anthracomya Phillipsi occurs; also to show the relation of Ancylus $V i n t i$, Kirkby (Carbonicola Vinti, Hind), to Anthracomya Phillipsi as they occur associated together in this section, and to give as complete a list of the fauna and flora as possible. Dr. Trechmann and I certainly never thought 
we were the first to record Anthracomya Phillipsi from this bed, and are sorry if Mr. Stobbs thinks we have done him an injustice by omitting to refer to the papers he mentions.

David Woolacort.

August, 1919.

GAPS IN THE MUCRONATA CHALK OF THE ISLE OF WIGHT.

Srk,-Last autumn I happened to be in the neighbourhood of Ryde Waterworks and paid a visit to the "pit" there (No. 45 of Dr. Rowe). I found on the talus two fossils, which, owing to a long illness which has left me crippled, I was only recently able to examine thoroughly. 'They proved to be unmistakable specimens of Echinocorys scutatus var. subconicus, a typical and exclusive fossil of the zone of Bel. mucronata. 'They were found at the extreme south end of the talus and presumably came from the sonth end of the exposure. This end of the exposure is at least 150 feet from the Chalk boundary as mapped, and though the dip at this point appears to be unusually low for the central ridge it should be safe to take it as at least $60^{\circ}$, which would give a minimum of 100 feet of mucronata Chalk at this point.

This makes the third of the five alleged instances of a breach completely through the mucronata zone to be definitely discredited. 'The other two instances, near Freshwater, remain subject to the criticism which I passed on them in the Geological Magazine for A ugust, 1918, reinforced by the fact that in the northern part of the pit, west of Freshwater, I have found Membraniporella manonia, which in my experience is rigidly confined to the lower part of the mucronata zone, and Herpetopora, a genus which is extremely rare in the quadratus zone, but in the Isle of Wight is almost abundant in the mucronata zone.

May I take the opportunity of recording that I have found brachials, presumably of Vintacrinus, in the upper part of pit 36 of Rowe, who does not record Uintacrinus there, although he maps it, and at the head of Freshwater Bay on the west side, which involves some shifting of the mapped boundary, and that the Isle of Wight has had scant justice done to it as a locality for Stephanophyllia. I have examined the T. lata Chalk of Compton Bay on three occasions for periods ranging up to three-quarters of an hour, and $\mathrm{my}$ smallest bag was ten specimens. I found two specimens in my only search of the same zone at Culver Cliff, and five in a short search of the $H$. subglobosus zone of Compton Bay. With specimens from the Chalk Marl and Chloritic Marl of the Isle of Wight, and of course elsewhere, and a specimen from the quadratus zone of Sussex to bridge the gap between the well-known cor-anguinum occurrences of Kent and the abundance of Studland (where, after Dr. Rowe's party had swept the section, I once found sixteen specimens in a day) and Weybourne, Stephanophyllia is much more freely distributed in the Chalk than is likely to be generally realized.

27 Maybury Manstons,

R. M. BRYdone.

MARYLEBone STREET, $W$. September 20, 1919. 